\title{
Yearning for Justice: A Testimony from Rohingyas Misery in Bangladesh
}

\author{
Nasir M. Ali* , Ayan Rashid Ibrahim \\ Institute for Peace and Conflict Studies \\ University of Hargeisa, Somaliland \\ *Corresponding author's email: nasimali [AT] yahoo.co.uk
}

\begin{abstract}
The Rohingya crisis has been a global news item both in newspapers and television in most recent times. The central objective of this study is to investigate the causes and drivers for uprooting the Rohingyas andforcing them to leave their ancestral land and to unveil the distressing and destitute situation of the Rohingyas from the refugee camps. The evidence that emerges from this study is that the Government of Myanmar is deliberately involving in the extermination and forceful displacement of the Rohingy as for political, ethnic, religious, and economic ends. Reacting to what is happening in the Rakhine State of Myanmar, a top United Nations human rights official considered a "textbook example of ethnic cleansing". The study calls for the international community to hold Myanmar state accountable to its acts of mass execution and annihilation of its citizens, and permit the Rohingyas to return to their ancestrallands in Myanmar.
\end{abstract}

Keywords --- Rohingya, minority, genocide, ethnic-cleaning, Myanmar, Bangladesh

\section{INTRODUCTION}

One of the major sources of the conflicts and contentions taking place in the developing world is the social exclusion and marginalization of certain ethnic groups or communities from state opportunities. This is a challenge not only in the developing world but remain s constant challen ge in the developed countries, too. Brian (2002:192) eloquently cited Tony Blair's as sertions who described socially excluded people as, "the people who do not have the means, materialor otherwise, to participate in social, economic, political and cultural life". Sheppard (2006:7) described social exclu sion as the dynamic process of being shut out, fully or partially, from any of the social, economic, political, and cultural systems which determine the social integration and cohesion of a pers on in society.

It is widely known that lack of inclusive development, social exclusion, and marginalization of certain communities within the state premises, lack of employment opportunities, manipulation of power, and accumulation of ill-gotten res ources by a few serve as key drivers of conflicts and cris es among the community and their state as well. As such, these drivers make the state weak and poorly resourced. While the states are res ponsible for delivering the core social services and security to the citizens, fragile states provide only limited es sential services. However, the delivery of a range of other desirable political and social services becomes possible when a reas onable measure of security has been sustained (Robert, 2003). Therefore, the failure of the state to provide basic services to its citizens and its inability to meet people's expectations are the drivers igniting fragility (OECD, 2010). This kind of state practice, therefore, dis rupts the euphoria of its citizens and delegitimizes the stateinstitutions.

The argument advanced here is that the socialexclusion theory is inextricably linked with human needs. In this regard, the inability of the s tate to meet citizens' basic needs can make states vulnerable. Con sequently, citizens have only two options. The first option has to do with revolt against their state. The second option has to do with leaving the country in search of better living standards. To further this point, theinability of the stateto provide its citizens with the services needed, or the marginalization of certain citizens from the state opportu nities, remains the major s ource of migration. The migration takes place either in the form of forced or voluntary displacement. The first formis evident with regard to the Rohingy acris is in Myanmar where the state itself denies national identity of the Rohingyas and their belongingness to the Myanmar state. According to Syeda N. Parnini(2013) upon the denial of citizens hip following the military takeover of the country in 1962 , the Rohingyas were subject to widespread persecution in their native country of Myanmar, where they became stateless without a legal nationality which forced many of them to migrate to Bangladesh as refugees. As of today, however, the government of Bangladesh does not officially recognize themas refugees. 
Such a situation compelled them to travel far and wide over the past five decades desperately seeking refuge and a better life (Syeda, 2013). In this case, the failure of political systems to consis tently meet people's social and material expectations can translate into a negative mood that instigates political action. Gurr (1970) and Brush (1996), respectively argue that relative deprivation results from the combined effect of rising expectations and a lack of progress toward demands for a better life. An intolerable gap between anticipated reality and the manifest reality of conditions of life serves as a precondition for wides pread unrest. Therefore, rapid social change, es pecially coupled with an uneven distribution of wealth and power, tends to generate feelings of a growing gap between immaterialized expectations and perceptions about existing economic, social, and political conditions. This is true in case of the Rohingya crisis, and the rise of Arakan Rohingya Salvation Army (ARSA), a Rohingya insurgent group allegedly active in Rakhine State, should be reg arded as a response to a catalog of grievances accumulated by the Rohingyas for decades, which has finally opted to respond violently.

The Rohingyas experienced various forms of ethnic and religious persecution. While women are tortured and their hands tied up for rape, the male have been killed, maimed and humiliated in the face of their people, while their houses were torched, mosques and schooled were razed. This study is not going beyond examining the situation of the Rohingya people in the refugee camps in Cox's Bazar, Bangladesh. The study tries to unveil the shocking situation of above one million involuntarily displaced Rohingyas who are now living in an abject, destitute, and deeply discouraging condition. The study questions why the Myanmar leader, Aung San Suu Kyi who was awarded the Nobel Peace Prize in 1991 is defending the atrociou s acts of the military against her own citizens. While many human rights individuals and organizations are voicing their concerns over the tragedies and agonies happening in the Rakhine State of western Myanmar, the international community, on the other hand, has said little words about the grave violations of human rights against the Rohingyas in Myanmar. This is showing the hypocrite nature of the international systemand how it protects those who engage in mass killings becau se of their alliance with a superpower. The study proposes possible options to protect the Rohingyas and help themreturn to the ancestral land they lived for generations without prejudice.

\section{FROM CITIZEN TO ALIEN}

Making alien some segments of society is becoming a norm in some countries. It is generally known that citizens' competition over national res ources and ownership of the means of production poses a dilemma on state-building and capacity in Africa. South Sudan's case, both prior and post-independence, is a class ic example. The South Sudanese have been poor because they experienced an extreme form of exclusion and marginalization from state opportunities. Being far from the decision and policymaking circles, it has remained one of the most marginalized parts in main Sudan due to the absence of modern governance structures to provide essential social services, economic development, and other benefits to the citizen s (Abdelghaffar, 2008; Idris, 2008). However, the is sue of underdevelopment, economic marginalization, and unequal dis tribution of state resources and wealth among the Sudanese citizens, should be directly linked to the notion of oppressor and oppressed. The South Sudanese people were indeed oppressed and excluded from the national opportunities. In this, Bulhan (1985) argues that the oppressed are the primary victims of structural violence and the prevailing paranoia and remain victims of others and of themselves.

One of the root causes of the conflict between the ethnic Rohingya group on one hand and the Buddhist majority on the other hand, is a colonial legacy. In the Second World War, the Rohingyas allied with the British colonial rule while the Buddhists which are the majority of the 135 Myanmar dis tinct ethnic groups allied with the Japanese (Hans-Bernd, 2017; Andrew, 2018). The political and racial differences between those ethnic groups and their alignment with two different opposing powers have been the source of violent clashes with mas sacres which fueled a prolonged hatred and contributed greatly to the subsequent segregation of the Rohingya ethnic group (John, 2018). This political alliance between the British and the Rohingyas shaped the future political relations between the Rohingyas and the Buddhist-dominated state of Myanmar (Zezen, 2018), and has deepened the asymmetrical relations between thoseethnic groups that made the outcome uncertain. In an attempt never accepted by the Britis h, the Rohingyas leaders called for the British rule in Burma to annex their region into Eastern Pakistan, the present-day Bangladesh, or make an independent state (Mohammad, 2019). This was aimed to avoid future political, economic, and social suffering of the Rohingy as.

In the post-independence Burmese state, the Muslims have had a representation both in the executive and legis lative branches. However, during the military regime from 1962 to 1995, no single Muslim was appointed as a minister or even as a deputy minister. This is clear evidence of the level of discrimination and segregation against the Muslims in Burma. In the Muslimdominated regions in My anmar s tate, no single Muslimofficial, in all government offices in regions (Syeda, 2013; Hans-Bernd, 2017) such as the Rohingya state of Rakhine, were appointed military and security officials. This complicated the situation and forced many Rohingyas to leave from the country due to the repressive character of their own state. 
Identity is necessary for a state to officially recognize its people, and for the international community to address issues concerning the people (Nehginpao, 2019). It is evident that social exclusion and marginalization are multi-faceted and multi-dimensional and dis regard any single explanation and definition. However, there is an extreme form of social exclusion and marginalization, where the stateless Rohingya people in Myanmar are a typical case in point. Since 1978, the Rohingy a have been subject to a state-sponsored process of destruction and annihilation (Syeda, 2013; Zezen, 2018). The Rohingyas have deep his torical roots in the borderlands of the Rakhine State of Myanmar and were recognized officially, both as citizens and as an ethnic group by three successive governments of post-independence Myanmar (Amer et al. 2013; Hans-Bernd, 2017; Azad et al. 2018; Zezen, 2018). This emphasizes the fact that Rohingyas have been represented both in the executive and legislative branches of the state before the military rise to power in 1962.

However, the 1982 Citizens hip Law of Myanmar ignored the Rohingya's claim to citizenship. Thus, the law rendered them stateless which has formed the legal basis for arbitrary and dis criminatory treatment against the Rohingya community and made them subject to a series of draconian policies and controls (Brinham, 2019). However, this social and political marginalization of the Rohingyas intensified in the 1990s and in the post-2012, when the Rohingyas have been subject to renewed waves of hate campaigns and accompanying violence and extrajudicial killings aiming at destroying them and permanently removing them from their ancestral homes in the Rakhine State (Alice \& Maung, 2019). Not only the military which massively campaigned to uproot the Rohingyas from their ancestral lands but the Buddhist majority in the region who lived side by side with the Rohingyas were als o involved in carrying out brutal and callous acts against the Rohingya, such as razing Rohingya homes, schools, mosques, and villages, killing elderly people and raping the women (Azad et al. 2018; John, 2018; Syed, 2018). Such merciles s acts had been backed by themilitary and other Myanmar state ins titutions.

In what appears to be a crime ag ainst humanity and forced migration, the Rohingyas extremely face the repressive character of their state. Myanmar denied the belongingness of those citizens but forced themto leave their ancestral lands by using the Myanmar military to exterminate them(Syed, 2018; Brinham, 2019). Indeed, this is one of many heartbreaking stonies that any visitor can easily hear from the makeshift refugee camps in Bangladesh. The human rights of the Rohingyas are on the whole being ignored by their country and the international actors who said little words about the atrocities taking place in Myanmar (Amer et al. 2013; Zezen, 2018). The current situation of the Rohingyas does not only need criticism but needs an action to end this human tragedy.

Besides denying their national identity and citizenship, the state also excluded them from s tate opportunities. Yet, no single Rohingya has everhad the chance to attend school, receive treatment from the state health facilities, or qualify to get job opportunities in their country. Rather, forced labor, removal of citizenship, depopulation of their communities, severeabuse of children, elders and women, the prohibition of freedom of movement, confiscation, and destruction of properties, eviction, birth and marriage control have been subjected to the Rohingya communities (John, 2018; Zezen, 2018). To elaborate the latter factor further, the Rohingyas are only allowed to have two children, while on the other hand, they are ordered to s eek permis sion from the Myanmar authority to marry.

This makes the Rohingyas the most traumatized, dehumanized, stigmatized, terrorized, and persecuted communities in the world (Amin et al. 2018; John, 2018; Zezen, 2018; Neh ginpao, 2019). Therefore, the most often asked question is: what is the position of the Myanmar state in a human rights protection protocols point of view? Myanmar is a party to all conventions protecting human rights including the Convention on the Prevention and Punishment of the Crime of Genocide; the Convention on the Elimination of AllForms of Dis criminat ion against Women; the Convention on the Rights of the Child (CRC); the Optional Protocol to the CRC on the involvement of children in armed conflict; the Convention on the Rights of Pers ons with Dis abilities; and the International Covenant on Economic, Social and Cultural Rights (Azad et al. 2018). The acts against humanity committed by the military make Myanmar a state categorically dis proving human rights protocols signed and approved by the international community.

Indeed, and according to the discussions with the Rohingya refugees in therefugee camps in Cox's Bazar, Bangladesh, the Government of Myanmar repeatedly claim that the Rohingyas are not indigenous people but have migrated from Bangladesh, a claim extremely rebuffed by the latter (Syeda, 2013; Amer et al. 2013). Des pite the Bangladesh government dis puting recognition of the Rohingya as citizens of Bangladesh, the Government of Bangladesh regards Myanmar's claim as a baseless justification to uproot the Rohingyas fromtheir ances tral land. This shows how the state which is supposed to be responsible to provide social and security services to its citizens, and equally responsible to defend them from the external and internal threats, has instead engaged in such horrible activities against its own citizens.

In today's world, the Rohingyacase is unique compared to the other cases that happened in the world in the known history. It is a reality that many countries have fought over controlling territories and people they havebeen claiming for a while. One of the examples is that Somalia and Ethiopia fought over the Somaliregion in Ethiopia twice (1964 and 1977-1978), when the British colonial rule relinquished the region to Ethiopia in 1954(Bereket, 1980). After independence in 1960 and the subsequent unification of British Somaliland and Italian colony of Somalia, the newly formed republic became a nation 
trying to become an all-inclusive state, and it intended to retake the Somalis scattered in different countries in the Hom of Africa and put themunder the blue with a white five-pointed star flag.

Somalia's attempt resulted in deadly conflicts and destruction (Ali, 2008). In 1964, less than four years after Somalia's independence, Somalia fought Ethiopia over the border (Jeffrey, 1998, Bulhan, 2008). However, though Somalia was claiming both the land and the people, Ethiopia has never questioned the ethnic Somalis living in the region and their belongingness to the Ethiopian state. This is different from Myanmar's position and its claim that the Rohingyas are not Burmese citizens but migrated fromits neighbor, Bangladesh.

\section{THE ROOTS OF ROHINGYAS MISERY}

The crises in the Rakhine State of Myanmar also known as Arakan State during the British colonial rule (Mohammad, 2019) have both ethnic, religious, and resource dimensions similar to many state-sponsored crises aimed to control resources (Hans-Bernd, 2017; Amin et al. 2018). One of the fundamentals underpinning the Rohingy a displacement is Myanmar's state interest to take over the Rohingya's ancestral land for at least two broad reas ons: to depopulate the Rohingyas from Myanmar state and force them to cross the border between Bangladesh and Myanmar (John, 2018; Syed, 2018), and lease their land to foreign companies, in particular, to Chinese and Indian companies.

According to satellite images, the land dis placed from the Rohingy as was cleared by companies. This signifies how the Myanmar state is committed to uproot the Rohingya people from their land and hand over to foreign companies for investment purposes. It is not a surprise to lease the land for foreign companies for investment opportunities, but denying the rights of their belongingness to Myanmar State and alienating themby excluding them fromthe list of the 135 dis tinct ethnic groups recognized by Myanmar, remains one of the critical and difficult questions that both Myanmar State and the international community cannot respond to yet.

The Rohingyas are the most persecuted communities in the world (Amin et al. 2018; John, 2018). However, it was and remains the prime responsibility of the Myanmar State to relocate those people to other regions if the government is interested to lease their territory to foreign companies for investment reasons. But, leasing foreign firms to Rohingya's ances tral land which they lived for generations was a scapegoat where the Government of Myanmar is avoiding to be seen as a government uprooting its citizens and purging them from their native country. However, since the adoption of the Citizen ship Law of My anmar in 1982 which ignored the Rohingyas' claim to citizenship, the Rohingya people have been experiencing social discrimination, marginalization, and exclusion fromstate opportunities (Syeda, 2013), including denial of their social reality and having access to primary education which is universal, access to primary health and potable water, and other infrastructures necessary for the survival of the humankind.

Though it is widely known that resource scarcities and allocation has been considered as one of the major drivers of contemporary world conflicts and crises (Collier, 2008), in Africa, resource conflicts have been the defining character of Africa's ethnic and state confrontations (Ali, 2008; John, 2008; Paul, 2008). The conflict in Sudan's Darfur region is a classic example. In this, the root cause of the conflict was a contest over resources. The Arab dominated govemance structure in Sudan opted to displace and take the land of the African Muslims living in Darfur. This move has been driven by a range of factors including economic and political marginalization, and land use, and ownership differences (Bromwich, 2009; Paul, 2012). Not only in Darfur but also the ongoing conflict in the Congo is predominantly a conflict over the massive endowment in natural resources, including minerals, oil, water, forestry, and agricultural land abundant in the Democratic Republic of Congo (UNECA, 2015). In this respect, the neighboring communities and the state itself closely monitor those resources and sometimes generate conflicts either within the communities or with the state and its citizens.

Equally, religion and religious rituals are reg arded as one of the causes of conflicts in the world (Farhan, 2012). The Uighur Mus lims in China, a minority ethnic group primarily from China's northwestern region of Xinjiang face the extreme form of human rights abuses from China's socialist government. Though many international organizations and foreign governments urged the Chinese government to end the crackdown against its citizens, the Chin a state continued its arbitrary detention and punishment against the Uighur Muslims (Christopher \& Yuhui, 2016; Human Rights Watch, 2018; Is abelle $\&$ Wei, 2019). Similar to China, India's government led by Narendra Modi has been engaging in undermining India's Muslim status and citizenship (Human Rights Watch, 2020). This kind of practice, however, sparked riots and protests against the Bharatiya Janata Party-led government in India.

The Rohingya, a Muslim minority and the second-largest ethnic group in the Rakhine State of Myanmar which is the poorest and among the most is olated regions of Myanmar (Amer et al. 2013), face similar challenges and problems that many Mus lims in China and India are facing. Therefore, the religious identity of the Rohingyas and their belongingness to Islam (Amin et al. 2018; Syeda, 2013) is one of the major drivers if not the sole factor that pushes the Myanmar state to 
exterminate and force the Rohingyas to leave fromthe land they lived for generations. While the Muslim Rohingyas are persecuted and remained stateless in Myanmar, another ethnic group, the Kaman, is a recognized Muslim minority with citizenship rights in Rakhine State (Amer et al. 2013). This, however, disproves the idea that links the denial of the Rohingya's citizenship rights with their faith, but the conflict and crisis have an ethnic and racial root.

\section{DISPATCHING TESTIMONIES FROM MAKESHIFTS CAMPS IN UKHIA}

The Rohingyas, one of the most ethnically and religiou sly persecuted and discriminated communities in the world has been facing continued marginalization and displacement from their ancestral land by the military and the government of Myanmar in the last five decades (Amin et al. 2018). However, what happened in 2017 awakened the global community in which more than half a million Rohingya people fled their native country of Myanmar in the face of brutal attacks and constant persecution by the state of Myanmar itself (Azad et al. 2018). The testimonies in this part emerged froma work published by Liberation War Museum in Bangladesh which was an outcome of consecutive field visits aimed to collect human narratives to explore the real stories and tragic tales faced by the Rohingy as. The second source of the testimonies is another field visit arranged by the Liberation War Museumto the makeshift camps of Ukhia in Cox's Bazar, where one of the authors of this article visited to witness the tragedy and misery faced by the Rohingyas.

One of the Rohingya refugees who is in his late forties in the Kutupalong refugee camp shares his experience with the study and narrates how the uprooting started. One day, according to him, a high ranking military officer in his locality whom he knew before came to him and ordered themto leave from the village. The refugee stressed that he did not take the order seriously and just continued his work as usual. The next day, the military officer came to him and repeated the same mess age by saying that: "the people of the village should leave from this locality". The refugee replied: "where shall we go". According to him, the military officer said to him: "Go to the next village”. The refugee res ponded: "If we are going to the next village, whyare we leaving from our locality". The next day, the elders of the villageincluding him went to the military's camp and requested the army officers further details and why the military was ordering them to leave from the locality. The military officer gave them the last order and chance to leave from the locality by saying that: "this is an order from the top, and you have a chance to leave from the locality peacefully, otherwise the military will take harsh measures against you, and will force you to leave”. Finally, the military started its campaign against the village and cleared it by using thenational army.

This refugee states that the casualties were many and the military involvement in the mas sive campaign to displace the Rohing ya was horrible. The military and the radical Buddhis ts who were living with Rohing ya in the Rakhine State blocked the roads and checkpoints. According to him, the military and the Buddhists forced themto cross the river, the Naf River, forests, and mountains which was intolerable to the children, the women, and the elderly. According to him, with continuous walking, it took them sixteen days to cut a dis tance of 80 kilometers to arrive at the Kutupalong refugee camp in Cox's Bazar in Bangladesh.

The report “The Rohingya Genocide: Compilation and Analysis of Survivors' Testimonies" compiled by theCenter for the Study of Genocide and Justice at Liberation War Museumof Bangladesh in 2018, carries numerous shocking testimonies provided by the Rohingy a women describing the atrocious crime of rape and sexual violence committed against themby the perpetrators being the Myanmar army and the Rakhine Buddhists. Rohingya women, indeed, were raped and their rights violated while they were fleeing from their homes, and hiding in the jungles, or even snatched away from their houses. Unfortunately, women were tortured by their hands being tied up and then being raped, either individually or through gangrape.

The testimonies collected unveil outrageous tales of Rohingya women being raped and violated sexually through the invasion of force. The question that aris es fromhere is: who are those who are violating the rights of the Rohingyas women, children, male and elderly? The Myanmar military along with the local Buddhists detained Rohingya women in schools and raped them leaving them to die. Detention in schools which were converted to camps by the local Myanmar Police expres s es the forceful intention in committing such crime (Azad et al. 2018). Almost all the testimonies illus trate a similar pattern of crime committed by the Myanmar military forces. According to the 2018 report, the attacks were widespread and systematic as they took place throughout the area of the northern Rakhine state. The burning down of houses, killing men, dragging women to school premises and jungles shows the systematic and organized military strategy used by the Myanmar military forces along with the local "Maghs" (Ibid). The Maghs are one of the ethnic groups in Myanmar who are the Arakanese descendants. This ethnic group is also found in Bangladeshand known as Marmas mostly living in the Chittagong Hill Tracts as well as in the hilly region of Tripura state of India.

A daughter of Koiy a Bazar in Rakhine state aged 19 years portray thehorrific experience with a team from the Center for the Study of Genocide and Justice in the makeshifts camps in Ukhia, Cox's Bazar in 2018. The victim pictures what happened to her along with her family in the following statement: "Myanmar's military forces attacked our home. They 
beat my parents and my brothers. The military forcefully snatched me and my two younger sisters from my familymembers. When my parents tried to protect us the military beat them and shot them and forcefully locked me and my two sisters into a separate home. They separated me from my two other sisters and confined us. 3 to 4 (three to four) military people imprisoned me and my sisters and raped us repeatedly."

The tes timonies collected by the Center for the Study of Genocide and Justice at the Liberation War Museumin Bang ladesh are diverse at the same time shocking and painful. A lady aged around 28 years from Sohagpara in Maungdaw in the Rakhine State of My anmar als o narrated what has happened to her and her people. She stated the following: "Women came without clothes here. We didn't have any clothes. We have been assaulted in the name of being inspected for carrying valuable items in our body. Army and local Buddhists harassed us and searched our body with cruel and sexual intentions. Women ofall ages were subject to rape, although the initial target was theyounger women." This is not the only shocking story in the 2018 report released by the Center for the Study of Genocide, but numerous others break the hearts of those who have a sense of humanity.

Albeit those heartbreaking stories in the makeshifts camps of Ukhia in Cox's Bazar, for decades ethnic Rohingyas have been experiencing continuous ethno-religious conflicts, between the Buddhist majority on one hand, and the Rohingyas minority on the other aggravated by the involvement of the army in mass killings, abject poverty, racial hatred, denial of ancestral rights, severe humanitarian violations, genocide acts perpetrated by both the military and the pro-government non-Rohingya ethnic groups, surrounded by nations themselves struggling for controlling few resources in the region (Hans-Bernd, 2017; John, 2018). Unfortunately, the Rohingyas have suffered decades-long of state-sponsored stigmatization, dehumanization, and discrimination, where theirown state terrorized, slaughtered, isolated, segregated, and confined themin tightly securitized villages.

While the international community has been watching or saying little words about the ongoing atrocities against the Rohingyas, the Government of Myanmar systematically weakened the Rohingy as through hunger, illnes s, denial of their national rights and loss of livelihood which all place the Rohingyas at high risk of annihilation (Zezen, 2018). Regrettably, this continuous intervention resulted in many deaths and disappearances among the Rohingyas' unarmed civilians and destroyed the little properties they had. This state-sponsored campaign has no contribution to the already deteriorating lives and livelihoods of the ordinary Rohingyas, for whom life is not getting any easier.

In this regard, Myanmar's state-sponsored campaign against the unarmed civilians of the Rohingyas is categ orically ethnic cleansing. Stressing the latter argument, the top official of the United Nations High Commissioner for Human Rights described the pattern of gross violations of the human rights experienced by Rohingya as a widespread or s ystematic attack ag ainst the community, possibly amounting to crimes ag ainst humanity (UNHCHR, 2017). In this case, in a response to what is happening in Myanmar against the Rohingyas ethnic group, the United Nations top official described it as a "textbook example of ethnic cleansing".

\section{ROHINGYA'S FATE IN A DILEMMA}

The Rohingyas are estimated overtwo million people scattered in many countries in South Asia, predominantly Myanmar and Bangladesh (Amer et al. 2013). In Bangladesh, over one million Rohingyas are living as refugees where the Government of Bangladesh is refusing to recognize them as refugees (Syeda, 2013; Syed, 2018). Given the emphasis on this point, the Government of Bangladesh doesn't recognize the Rohingya people as its native citizens but welcomed and received as involuntarily dis placed persons for humanitarian grounds. This is contrary to Myanmar's continuous claims labeling the Rohingya people as the citizens of Bangladesh.

The Government of Myanmar has never used the word "Rohingya" to intentionally detach the question of belongingness of the Rohingyas to Myanmar and urges its media, the entire government institutions, and even the international organizations working in My anmar to instead refer to those people as "Bengalis". Labeling them as Bengalis is directly as sociating them with Bangladesh (Zezen, 2018; Nehginpao, 2019). The claims and counter-claims of those countries complicated the situation, as the Myanmar state is not ready to discuss with any country or org anization about the fate of the Rohingyas.

While over 400 thousand Rohingyas are enclosed in a maximum-security open camp in Myanmar where access to information is very limited or in reality absent, the over one million Rohingya refugees who are currently staying in Bangladesh, are also facing restrictions in the refugees' camps to walk outside the camps in a fear to infiltrate into the other parts of the country. Indeed, the Government of Bangladesh does not allow any refugees to come to the cities and also bans intermarriage between the Bangladesh citizens and the Rohingyas in an attempt to avoid acquiring a Bangladesh identity and citizenship. 
However, the denial of their social reality by the Myanmar state complicated the situation and rais ed so many questions within the Rohingya refugees in the makeshifts refugee camps in Bangladesh. As a consequence of accumulated grievances of Rohingyas against My anmar State, the radicalization of Rohingyas at the refugee camps will pose security threats to both Bangladesh and Myanmar (Zezen, 2018). The latter has denied the Rohingya's right to their national identity and is at risk to take the dis proportionate part of the threats that Rohingyas may pose on Myanmar.

Unfortunately, the Rohingyas are living in a situation entirely discouraging, which has social, economic and political dimensions, not only when the Government of Myanmar started uprooting the people from their ancestral lands, but also decades back when Myanmar ignored the Rohingya's right to citizenship, as well as their political, social and economic rights. However, the relation s between the two countries could be regarded as one as pect of the crisis. For instance, while the three Bay of Bengal States: Bangladesh, India, and Myanmar settled their long-standing dis puted claims over the maritime zones in the Bay of Bengal in a peaceful manner (Aniruddha, 2018), the non-cooperative diplomatic position of the Myanmar government towards the government of Bangladesh as well as towards the whole Rohingya cris is, will not solve the problem of the Rohingyas; rather it will escalate the situation and complicate it than expected.

However, the major res ponsibility remains on the shoulders of the Government of Myanmar which is responsible for the crimes and atrocities faced by the Rohingyas. Therefore, those who perpetrated the situation should be held accountable for the acts and the grave violations of human rights they committed. Unless this situation was res olved by the actors of the conflict, the Rohingya people will remain between a rock and a hard place.

\section{ENDING ETHNIC TARGETING AND MASS KILLINGS}

One of the key human rights is sues that the international community and Myanmar pro-democratic and ethnic activists have failed to address is the continuing statelessness, marginalization, dehumanization, and stigmatization of the Rohingyas (Amer et al. 2013). The international community has been silent about the mas sive atrocities and genocide acts committed agains the Rohingya people by their own state and government (Nehginpao, 2019). Grave violations of human rights have been committed by the Government of Myanmar, the military, and non-Rohingya ethnic groups, es pecially the radical Buddhists.

Although the Advis ory Commission on Rakhine State led by Kofi Annan (2016) and Independent International FactFinding Mis sion on Myanmar (2017-2019), and Independent Investigative Mechanism for Myanmar (2019-till now) are there (UNHCHR, 2019). The Suu Kyi-led government was never interested in the recommendations proposed by the Kofi Annan commis sion which released their report a few days before the military's offensive against the Rohingyas. One of the recommendations calls for the Government to examine the root cause of the conflict and suggested the review of the 1982 law which bans the Rohingyas to qualify for a national identity and citizenship (Syed, 2018). Other than the cases now pending in the International Court of Justice (ICJ) and International Criminal Court (ICC), civil societies have also initiated domes tic litigations for the protection of the Rohingyas, for instance, in Argentina, Australia, India, to name but a few.

As part of this process, a tiny West African country of Gambia broke the silence of the international community. In 2019 , the Gambian foreign affairs minister visited the Rohingya refugee camps in Cox's Bazar in Bangladesh lis tening to survivors' stories and how they began crossing the border into Bangladesh from Myanmar. The Gambian Government filed a cas e against the Government of Myanmar in the ICJ. This is one of the major voices which rais ed the Rohingya's ques tion of national identity and belongingness to their native country of Myanmar at global platforms. However, despite all the efforts globally and nationally, the $\mathrm{UN}$ is still staggering on this issue largely due to the problem of leaning to a superpower.

The United Nations Office on Genocide Prevention and the Res ponsibility to Protect should take the lead and bring those involved in this genocide into justice. Article 2 of the Convention on the Prevention and Punishment of the Crime of Genocide adopted in 1948 and entered into force in 1951 defines the term "Genocide" as acts committed with intent to destroy, in whole or in part, a national, ethnic, racial or religious group, as such: killing members of the group; causing serious bodily or mental harm to members of the group; deliberately inflicting on the group conditions of life calculated to bring about its physical destruction in whole or in part, to name but a few (John, 2006; William, 2009). Therefore, the crimes committed by the Myanmar state army qualify under the definition of the term genocide in international law. Amusingly, Myanmar is a party to all conventions protecting human rights.

In the post-Cold War era, societies and individuals have become the primary concern of the is sue of security. In the mid1990s, human security emerged as a hallmark of the concept of responsibility to protect. This concept has not eliminated the role, responsibility, and sovereignty of the state, buthas certainly altered the power of the state(Antonio, 2006). During this period, the world witnessed several state-sponsored crises which include Cambodia, Serbia, Rwanda, Burundi, and Kos ovo, to name but a few (Miller \& Pal, 2018). For instance, theNATO-led forces launched a military intervention against 
Slobodan Milošević of Serbia in res ponse to his military incursions against predominantly Muslimethnic Albanians living in Kosovo. What is happening in the RakhineState of Myanmar orchestrated by the state army of Myanmar is not different from what the Milošević of Yugoslavia did in Kosovo against the Muslims living in their native country of Serbia.

This is showing the hypocrisy of the international system and how political and economic interests always influence the decisions of those who lead and are architect of international politics. Therefore, the Rohingyas who experienced the extreme form of execution and marginalization fromtheirown state are yearning for justice, and it is the responsibility of the international organizations, in particular, the global body, the United Nations to advocate for the rights of the most marginalized, persecuted and humiliated people in the world, the Rohing yas. Thus, force the Myanmar state to accept its citizens and give themback their ancestral land and their denied national identity.

However, the Government of My anmar has been reluctantly discussing the is sue of the Rohing yas with any external actor including Bangladesh where the two countries agreed at different times to set up a schedule for repatriating the Rohingyas to their homeland. However, while My anmar should be understood as a country that is unwilling to implement policies and strategies that focus on the Rohingyas and their social, economic and political existence, the major responsibility rests on the shoulders of theinternational community, which must pressure the Myanmar state to accept international norms and res pect the rights of the Rohingyas within the state of Myanmar.

\section{CONCLUSION}

It is unfortunate for the international community and those advocates of human rights to watch what is happening to the Rohingyas in Myanmar without taking any action. The deadly crack down of the Rohingyas by the Government of Myanmar through army offensive against unarmed civilians sends critical and diverse questions to the international community and underlines the credibility of the international system. Since the early 1980s when the military Government of Myanmar removed the rights of citizenship from the Myanmar Nationality Act and labeled them as an alien belonging to a foreign country, the Rohingy as have been exposed to acts of brutality, including mas s killings, dis appearances, torture, and sexual violence against women. However, this intensified in post-2012 when the military of Myanmar got involved in grave violations of human rights against the Rohingyas. Therefore, the international community should revoke the prize from Nobel peace prize winner, the Myanmar leader, for her silence, reluctance, and less intervention in the mass killings and gang rapes committed by her army, which are one of the gravest crimes under international law.

The Rohingyas are experiencing vicious forms and cycles of execution and dis placement in the Rakhine State in particular where this Muslimminority group is facing an extreme form of extermination and uprooting. The Rohing ya ongoing crisis, however, in dicates that Rohingya's fate is in dilemma, and therefore, if the international community fails to end the massive atrocities and genocide committed against the Rohingyas, the crisis will escalate and the region will be in danger to submerge into a war that may erupt between the Rohingya and the Myanmar state. While the major cause should be regarded as a denial of the Rohingya social reality and their belongingness to the Myanmar state, there is, on the other hand, economic and religious enmity between the Rohingy as and their state, and in the end, this may plant seeds of radicalization and extremis min the future.

In this regard, while the Rohingy a cris is has polarized the entire region, Bangladesh took the disproportionate part of the crisis and hosts the largest Rohingya refugees. However, the political relations between Bangladesh and Myanmar are extremely on a fragile stage at least for two reasons: one is the is sue of the refugees' crisis which has been the defining factor of the two nations relations since the 1970s, where Myanmar's successive governments have been using a delay tactical to Rohingya's repatriation, and the second point to note is the maritime dis pute between the two countries on the Bay of Bengal. The second which was a long-standing dis pute claim over the maritime zones in the Bay of Bengal, the three Bay of Bengal States: Bangladesh, India, and Myanmar finally settled the dispute in a win-win manner.

However, the regional states have no common position in the Rohingya cris is. The political differences between the states in the region has invited other regional actors that complicated the situation than expected. Thus, fueled the conflict pursuing their own national interests and extend support to one of the major actors of the crisis. For instance, the Government of Myanmar gets support from China, India, and Russia for their own political and economic calculations.

The crisis of the Rohingyas has an ethnic and religious root as well as a resource allocation dimension. Therefore, the future of the Rohingya remains only in the hands of the international community and the foreign countries that advocate for human rights values, should force the Myanmar state to accept its own citizens and treat them equally with the other 135 ethnic groups in Myanmar and recognize themas its citizens. The grievances and exclusions fromsocial, economic, and political opportunities expressed by the Rohingya ethnic group in Myanmar could lead to further conflicts and confrontations with the regional states in future. 
This can be avoided only if the international community and the South Asian countries, in particular, the Association of Southeast A sian Nations (ASEAN) take the lead in finding appropriate solutions to ensure that inclu sive development and social justice prevail in Myanmar as a whole, and the Rohingya's underdeveloped and is olated region in particular. The Rohingyas are poor indeed because they experienced prolonged state-sponsored exclusion and marginalization from the state opportunities since independence in 1948; therefore, the Rohingyas need to have a better life and better future for their next generations. Nevertheless, if the international community and the regional actors fail to settle the Rohingya crisis and their long demanding rights to nationality and citizenship, and not force the Government of Myanmar to respect the rights of the Rohingyas, more social and political instability will follow and certainly might have an adverse consequence on the wider region of South Asia.

\section{REFERENCES}

- Ahluwalia, Pal \& Toby, Miller (2018). The Rohingy a Crisis: Another Failure of the International Sys tem, Journal for the Study of Race, Nation and Culture, Vol. 24, No. 3. Pp. 291-292.

- Ahmed, Abdelghaffar M. (2008). "Multiple Complexity and Prospects for Reconciliation and Unity: The Sudan Conundrum”. In: The Roots of African Conflicts: The Causes and Costs (eds). Addis Ababa: OSSREA.

- Ahsan, Syed B. (2018). The Rohingya Cris is: Why the World Must Act Decisively, Asian Affairs, pp. 1-11.

- Akokpari, John (2008). “You Don't Belong Here', Citizenship, the State and Africa's Conflicts: Reflections of Ivory Coast”. In: The Roots of African Conflicts: The Causes and Costs (eds). Addis Ababa: OSSREA.

- Amin, Robed Md., Is lam, Mohammad R. \& Islam, QT (2018). Rohingya Cris is in Bangladesh: The Effect of Ethnic Cleansing in Myanmar, Bangladesh Journal Medicine, (29). Pp. 1-2.

- Attané, Is abelle \& Guo, Wei (2019). Social Mobility of Uighur Population in Mainland China: A Comparative Pers pective, Journal of Muslim Minority Affairs, Vol. 39, No. 4. Pp. 522-533.

- Azad, Emraan. Dasgupta, Shaoli. Hoque, Mofidul \& Rahim, Naureen (2018). The Rohingya Genocide: Compilation and Analysis of Survivors' Testimonies. Dhaka: Center for the Study of Genocide and Justice.

- Bereket Habte Selassie (1980). Conflict and Intervention in the Horn of Africa. United States of America: Monthly Review Press.

- Brendan, Bromwich (2009). “Analysing Resource Constraints as One Dimension ofthe Conflict in Darfur”. In: Environment and Conflict in Africa: Reflections on Darfur(ed). Addis Ababa: View Graphics.

- Brinham, Natalie (2019). “The Conveniently Forgotten Human Rights of the Rohingya”. In: Es s ays on Myanmar's Genocide of Rohingy as (2012-2018). Dhaka: CR Abrar.

- Brush, Stephen G. (1996). Dynamics of Theory of Change in the Social Sciences: Relative Deprivation and Collective Violence, The Journal of Conflict Resolution, Vol. 40, No. 4 (Dec. 1996), pp. 523-545.

- $\quad$ Bulhan, Hus sein A. (1985). Frantz Fanon and the Psychology ofOppression. New York: PlenumPress.

- (2008). Politics of Cain: One Hundred Years of Crises in Somali Politics and Society, $1^{\text {st }}$ edition. Bethesda, MD, USA: Tayosan InternationalPublis hing.

- Collier, Paul (2008). The Bottom Billion: Why the Poorest Countries Are Falling and What Can Be Done About It. New York: Oxford University Press.

- Cowley, Alice \& Zarni, Maung (2019). “The Slow-Burning Genocide of Myanmar's Rohingya”. In: Essays on Myanmar's Genocide of Rohingyas (2012-2018). Dhaka: CR Abrar.

- Dussich, John P. J. (2018). The Ongoing Genocidal Cris is of the Rohingya Minority in Myanmar, Journal of Victimology and Victim Justice, 1(1). Pp. 1-21.

- Franceschet, Antonio (2006). “Global Legalism and Human Security”. In: A Decade of Human Security: Global Governance and New Multilateralis ms (eds). England: Ashgate Publishing Limited. 
- Ghazali, Amer S., Othman, Mohammad R. \& Parnini, Syeda N. (2013). The Rohingya Refugee Crisis and Bangladesh-Myanmar Relations, Asian and Pacific Migration Joumal, Vol. 22, No. 1. Pp. 133-146.

- Human Rights Watch (2018). "Eradicating Ideological Viruses": China's Campaign of Repression Against Xinjiang's Muslims. New York: Human Rights Watch.

(2020). "Shoot the Traitors": Discrimination Against Muslims under India's New Citizenship Policy. New York: Human Rights Watch.

- Kipgen, Nehginpao (2019). The Rohingya Cris is: The Centrality of Ident ity and Citizenship, Journal of Muslim Minority Affairs. Pp. 1-14.

- Lefebvre, Jeffrey A. (1998). The United States, Ethiopia, and the 1963 Somali-Soviet Arms Deal: Containment and the Balance of Power Dilemma in the Horn of Africa, The Journal of Modern African Studies, Vol. 36, No. 4 (Dec. 1998), pp.611-643.

- Li, Yuhui \& Niemann, Christopher (2016). Social Construction of Ethnic Identity and Conflict: The Cas es of the Chechen and the Uighur, Journal of Muslim Minority Affairs, pp. 1-14.

- Lund, Brian (2002). Understanding State Welfare: Social Justice or Social Exclusion. London: Sage Publications.

- Mazrui, Ali A. (2008). "Conflict in Africa: An Overview”. In: The Roots of African Conflicts: The Causes and Costs (eds). Addis Ababa: OSSREA.

- Mutaqin, Zezen Z. (2018). The Rohingya Refugee Crisis and Human Rights: What Should ASEAN Do? AsiaPacific Journal on Human Rights and the Law 19 (2018). Pp. 1-26.

- OECD (2010). The State 's Legitimacyin Fragile Situations: Unpacking Complexity. Paris: OECD Publishing.

- Omani, Paul(2012). "Investigating the Link between Environmental Scarcity and Conflict in Darfur". In: Climate Change and Pastoralism: Traditional Coping Mechanisms and Conflict in the Horn of Africa. Addis Ababa: Eclipse Printing Agency.

- Parnini, Syeda N. (2013). The Crisis of the Rohingya as a MuslimMinority in Myanmar and Bilateral Relations with Bangladesh, Journal of Muslim MinorityAffairs, Vol. 33, No. 2. Pp. 281-297.

- Quigley, John (2006). The Genocide Convention: An International Law Analysis. England: Ashgate Publishing Limited.

- Rajput, Aniruddha (2018). Bay of Bengal maritime delimitation cases: Upholding the Rule of law in international relations, Maritime Affairs: Journal of the National Maritime Foundation of India, Volume 14, Is sue 1. Pp. 24 35 .

- Rotberg, Robert I. (2003). “Failed States, Collapsed States, Weak States: Causes and Indicators”. In: State Failure and State Weakness in a Time of Terror. Harrisonburg, VA:R.R. Donnelley.

- Salim El Has san, Idris (2008). "Managing the Process of Conflict Resolution in the Sudan". In: The Resolution of African Conflicts: The Management of Conflict Resolution and Post-Conflict Reconstruction (eds). Addis Ababa:OSSREA.

- Schabas, William A. (2009). Genocide in International Law: The Crime of Crimes, $2^{\text {nd }}$ edition. New York: Cambridge University Press.

- Selth, Andrew (2018). Myanmar's Armed Forces and the Rohingya Crisis. W ashington, DC: United States Institute of Peace.

- Shahabuddin, Mohammad (2019). Post-colonial Boundaries, International Law, and the Making of the Rohingya Cris is in Myanmar, Asian Journal of International Law, Volume 9, Issue 2. Pp. 334-358. 
- Sheppard, Michael(2006). Social Work and Social Exclusion: The Idea of Practice. England: Ashgate Publishing.

- Siddiqi, Farhan H. (2012). Security Dynamics in Pakistani Balochistan: Religious Activismand Ethnic Conflict in the War on Terror, Asian Affairs: An American Review, 39 (3). Pp. 157-175.

- Ted, Gurr (1970). Why Men Rebel. Princeton, NJ: Princeton University Press.

- UNECA (2015). Conflicts in the Democratic Republic of Congo: Causes, impact, and implications for the Great Lakes region. Addis Ababa: UNEconomic Commission for Africa.

- UNHCHR (2017). Darker and more dangerous: High Commissioner updates the Human Rights Council on human rights issues in 40 countries. Available at https://www.ohchr.org/EN/NewsEvents/Pages/DisplayNews.aspx?NewsID=22041\&LangID=E. Accessed on July 25, 2020, at 10:00 am.

- _ _ (2019). UN Fact-Finding Mission on Myanmar Hands Over to Independent Investigative Mechanism for Myanmar. Available at https://www.ohchr.org/EN/HRBodies/HRC/Pages/NewsDetail.aspx?NewsID=24960\&LangID=E. Accessed on July 30, 2020.

- Zelela, Paul T. (2008). "Introduction: The Causes and Costs of War in Africa-from Liberation Struggles to the 'War on Terror'”. In: The Roots of African Conflicts: The Causes and Costs (eds). Addis Ababa: OSSREA.

- Zöllner, Hans-Bernd (2017). Caught between the Crocodile and the Snake: Contexts of the 'Rohingya issue'. University of Windsor, Universiti Sains Malaysia and Bergh of Foundation. 